\title{
Analysis of Rubber Price Differences in Jambi Province
}

\author{
Mirawati Yanita, ${ }^{1 *}$, ErnawatI Hamid ${ }^{2}$, Zulkifli Alamsyah ${ }^{3}$ \\ ${ }^{1}$ Agribusiness Department, Agricultural Faculty Universitas Jambi \\ ${ }^{2}$ Magister Agribusiness, Universitas Jambi \\ *Corresponding author. Email: mirawativanita@unja.ac.id
}

\begin{abstract}
Rubber is the most valuable export crop produced by small scale agriculture and plays a crucial role in inclusive economic development. Rubber becomes very close to the farmers because of cultivation and processing techniques and provides economic value directly. Jambi Province also one of the third rubber producers in Indonesia. Although rubber plays an essential role as a source of farmers' income, they always get low prices and are different from other regions in the Jambi province. This research aims to describe the rubber marketing pattern from farmers to the Crumb rubber factory in Jambi Province. Secondly, it aims to analyse the rubber price differences in Jambi Province. The survey method was used at the Region with the highest price in Sarolangun District and the lowest price in Muaro Jambi District. The data collected were primary and secondary sources. The result showed that the pattern of rubber marketing in regions with low and high rubber prices has three marketing channels, but there are only high prices. Marketing institutions involved in marketing rubber produced by farmers are middleman, wholesalers, and crumb rubber factories, where efficient marketing channels are the shortest channel, both in areas with high and low prices. The high difference in rubber prices between the two districts is the difference in the quality of rubber materials, the marketing mechanism, and the frequency of rubber sales. In the future, both rubber farmers in the lowest and highest region price form a fixed farmer group to do rubber marketing and follow the government policy about the rubber processing and marketing unit to cut the channel marketing straight to the factories to get higher prices.
\end{abstract}

Keywords: Rubber, Rubber marketing pattern, Price differences, Marketing Efficiency.

\section{INTRODUCTION}

Rubber plants are plantation crops that have a stick in Indonesian people. Most farmers are already familiar with rubber plantations and their cultivation practices. Rubber becomes very close to the farmers because cultivation and processing techniques provide economic value directly for farmers [1]. The data in 2017 shows the total area of a rubber plant in Indonesia is 3.672 million hectares and occupies the third largest plantation area after palm and coconut. It is Cultivated by 2,502 million farmer families [2].

The quality of bokar (rubber's substance) produced by Indonesian rubber farmers is known in the international rubber trade to belong to low quality. The low rate of bokar causes Indonesian rubber's competitiveness is low, and the value seems more bass than the price of rubber production in Thailand, Malaysia, Vietnam, and India. The low productivity and quality of Indonesian bokar are because most of the rubber is cultivated in smallholder plantations that have not used many new technologies [3]. The low quality of bokar impacts the price that belongs to the farmers and getting lower. Most of the farmers produce in the form of thick slabs. This thick slab is the most inferior quality of rubber production. The low rate of bokar also causes the bargaining position of farmers to become weak.

Most of Indonesia's rubber plantation areas are located in Sumatra (70\%), Kalimantan $(24 \%)$, and Java $(4 \%)$. The rubber plantation area in Indonesia is spread 
over 22 provinces from 33 provinces. Jambi Province is the province with the 3 rd largest width rubber plantation in Indonesia [4]. The extent of rubber plantations in Jambi Province indicates this province as the largest rubber production centre area. Because in Jambi, many farmers rely on rubber plants as the primary source of livelihood in fulfilling the needs of life, compared to other plantation crops such as palm oil, coffee, coconut, and area.

Merangin district is the largest district area in Jambi Province with $19.88 \%$, and the smallest is Kerinci district that is $0.28 \%$. However, when the average price of rubber in Jambi Province was obtained in 2006-2018 varied over time. Farmers received the highest average price of IDR $11,110 / \mathrm{Kg}$, while the Muaro Jambi district farmers received the lowest average price of IDR $8.670 / \mathrm{kg}$ [5]. Farmers in rubber production centres in Jambi Province

This research was conducted in two regencies. Each of them has high and low rubber prices in Jambi Province, namely Sarolangun Regency representing the Region with the high price and Muaro Jambi Regency representing the Region with low price. Sarolangun district was selected sub-district and the largest village of rubber plantation area, Similarly for Muaro Jambi, Region, subdistricts, and villages are appointed with the largest area of the site.

The method used in this research was the survey method, considering the vast and large population of smallholder rubber farmers in both research areas. There are two study villages Jati Baru Village in Sarolangun regency and Bukit Baling Village in Muaro Jambi regency.

The data collected came from two sources: primary and secondary sources. To answer the purpose of the first study, a descriptive analysis was conducted by looking at the marketing channel of rubber materials from farmers to crumb rubber factory Marketing Margin,[6] [7] used the formula:

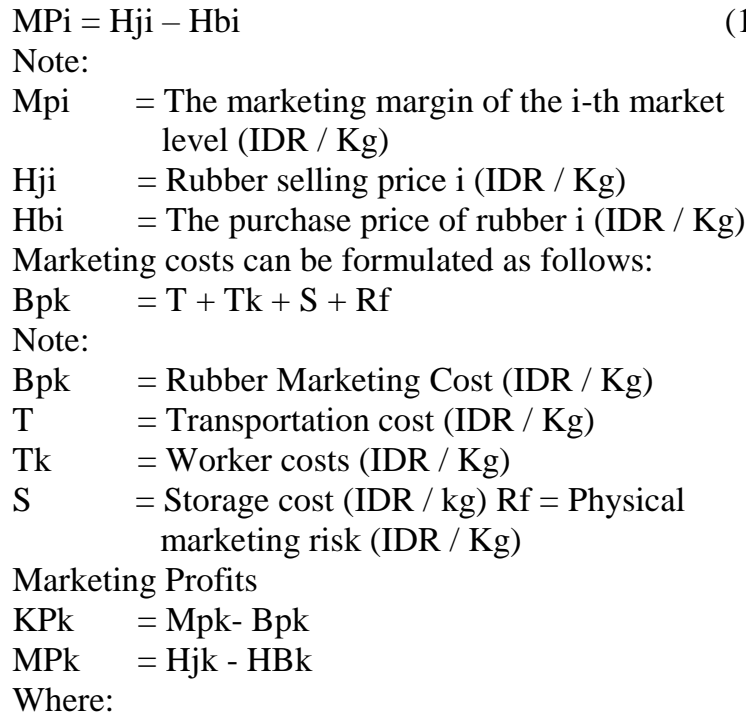$$
\mathrm{MPi}=\mathrm{Hji}-\mathrm{Hbi}
$$$$
\text { Note: }
$$$$
\text { Mpi = The marketing margin of the } \mathrm{i} \text {-th market }
$$$$
\text { level (IDR / Kg) }
$$$$
\mathrm{Hji}=\text { Rubber selling price } \mathrm{i}(\mathrm{IDR} / \mathrm{Kg} \text { ) }
$$$$
\mathrm{Hbi}=\text { The purchase price of rubber } \mathrm{i}(\mathrm{IDR} / \mathrm{Kg} \text { ) }
$$$$
\text { Marketing costs can be formulated as follows: }
$$$$
\mathrm{Bpk} \quad=\mathrm{T}+\mathrm{Tk}+\mathrm{S}+\mathrm{Rf}
$$$$
\text { Note: }
$$$$
\mathrm{Bpk}=\text { Rubber Marketing Cost (IDR / Kg) }
$$$$
\mathrm{T}=\text { Transportation cost (IDR / Kg) }
$$$$
\mathrm{Tk}=\text { Worker costs (IDR / Kg) }
$$$$
\mathrm{S}=\text { Storage cost }(\mathrm{IDR} / \mathrm{kg}) \mathrm{Rf}=\text { Physical }
$$$$
\text { marketing risk (IDR / Kg) }
$$$$
\text { Marketing Profits }
$$$$
\mathrm{KPk}=\mathrm{Mpk}-\mathrm{Bpk}
$$$$
\mathrm{MPk}=\mathrm{Hjk}-\mathrm{HBk}
$$

Where:

in the last 13 years received varying prices. The price difference received by farmers is due to the difference in the quality of bokar reflected from dry rubber content and the pattern of distribution or marketing of rubber from farmers to crumb rubber factories. It can be seen that there is a high price disparity between the district's rubber production centres. So, it needs to be seen how the pattern of rubber marketing from the farmer level to the crumb rubber factory and how significant the price differences happened in the central rubber-producing district in Jambi Province. The objectives of this research are to Describe the pattern of rubber marketing from farmers to Crumb rubber factories in Jambi Province. Second analysing the differences in the rubber price in Jambi Province.

\section{METHOD}

$$
\begin{array}{ll}
\mathrm{KPk} & =\text { The profit of rubber marketing (IDR } / \mathrm{Kg} \text { ) } \\
\mathrm{MPk} & =\text { Rubber marketing margin (IDR } / \mathrm{Kg} \text { ) } \\
\mathrm{Hjk} & =\text { Rubber selling price (IDR } / \mathrm{Kg} \text { ) } \\
\mathrm{HBk} & =\text { Rubber Buying Price (IDR } / \mathrm{Kg} \text { ) }
\end{array}
$$

Looking at the Efficiency of each marketing agency using the formula:

$\mathrm{EPb}=\mathrm{x} 100 \%$

$\mathrm{TNpb}=\mathrm{Hjb} \times \mathrm{Jbp}$

Where:

Epb = Efficiency of rubber marketing (percent)

$\mathrm{TBpb}=$ Total marketing cost of rubber (IDR)

$\mathrm{TNpb}=$ Total value of rubber sales (IDR)

$\mathrm{Hjb} \quad=$ Rubber selling price (IDR / $\mathrm{kg}$ )

$\mathrm{Jpb} \quad=$ Number of marketed rubber $(\mathrm{Kg})$

If: Ratio between 00 - 33 is Efficient

The ratio between 34 - 67 is Less Efficient

The ratio between 68 - 100 is Inefficient

Furthermore, to see the magnitude of marketing efficiency can be explained descriptively based on a fair share of the overall price paid to consumers and marketing costs as low as possible. The second objective will be answered through analysis of price differences between regions, which will be presented descriptively by identifying the price differences in each rubber production centre in Jambi province.

\section{RESULT AND DISCUSSION}

\subsection{General Description of The Research Area}

Jambi Province, as one of the fourth-largest producers of rubber in Indonesia, contributed 11.19 percent of the total rubber production in Indonesia. The total area of cultivation in Jambi Province is 665,306 hectares, with a total of 263,313 farmers. [8]. Table 1 below shows the area and production of rubber according to districts in Jambi Province in 2016. Merangin District has the largest rubber area, followed by Sarolangun, Tebo, Bungo, Batanghari, and Muaro Jambi districts. The area's 
contribution in Merangin Regency reached 18.86 percent, and Muaro Jambi Regency was 8.73 percent.

The selection of Sarolangun and Muaro Jambi Regencies was based on the fact that in Sarolangun district, the average rubber prices at the farm level were highest in Jambi Province. Whereas in Muaro Jambi Regency, farmers receive the lowest prices. The average price received by farmers in the Sarolangun district in the last 13 years was IDR 11,110 / kg. The lowest price in Muaro Jambi Regency is IDR 8.670 / Kg. Sarolangun Regency has ten sub-districts with average productivity of $956 \mathrm{~kg} / \mathrm{ha}$.

The data showed that Mandiangin sub-district has the largest number of heads of farmer families, namely 16.91 percent of total farmer households. The total area of rubber farms of household farmers in Mandiangin District is $29,764 \mathrm{Ha}$, successively the plants have not produced 8,343 ha, plants produce 13,811 $\mathrm{Ha}$, and damaged or old plants covering 7,610 $\mathrm{Ha}$. Mandiangin is a sub-district in Sarolangun District, Jambi, Indonesia. Mandiangin is an expansion of the area from Pauh subdistrict in 1999. Mandiangin District has 28 villages, of which there are ten villages that are the biggest producers of rubber. One of the villages that is a rubber-producing area is the new Jati village. This village is an extension village with Jati Baru village Mudo.

Furthermore, Muaro Jambi Regency is a district chosen as a district with the lowest bokar price at the lowest farm level in Jambi Province. (attachment 2,
Rubber distribution map as the leading commodity of Muaro Jambi Regency plantation) Muaro Jambi Regency has 11 sub-districts. The subdistrict chosen as the research sample is Sakernan sub-district. This subdistrict oversees 16 villages. The selected village is Bukit Baling village. Bukit Baling village is one of the suburbs with minimal road access. This condition makes it difficult for villagers to sell their garden products in the form of rubber and oil palm, to support their daily needs, but since 2017, the opening of a new road has been built from Bukit Baling Village to Sengeti Village. This road is access to sell garden produce. This village in the beginning, had an auction market since 1990, which was conducted every two weeks. But over time, as the number of farmers and traders transacted less and less, eventually, the farmers returned to selling their bokar to village collectors or middlemen.

\subsection{The Pattern of Rubber Marketing from Farmers to Crumb Rubber Factories}

The pattern of marketing in the area of low rubber prices as follows. The low-cost rubber production area in this study is Muaro Jambi Regency. This study's marketing pattern is seen from the marketing channels in the study area, namely the sample villages. The marketing channel consists of several marketing chains depending on several marketing agencies involved in marketing the bokar[9]. The following is the marketing channel for rubber-based ingredients in Bukit Baling Village, Sakernan Subdistrict, shown in Figure 1 below.

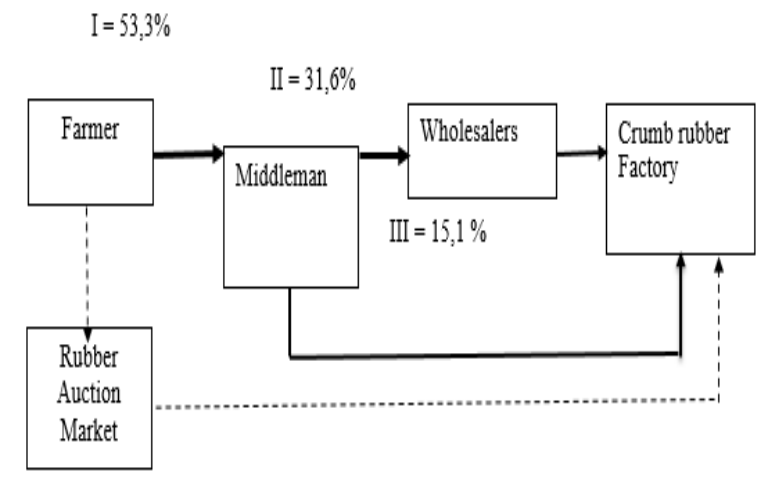

Figure 1. Chain of Rubber (Bokar) Marketing in Bukit Baling Village

Based on the marketing chain in Figure 1, there are three marketing channels for Bokar in Bukit Baling Village, Sakernan District. It consists of marketing channel I as much as 53.3 percent, marketing channel II as much as 31.6 percent, and marketing channel III as much as 15.1 percent of all farmers examples. A total of 32 farmers, or 53.3 percent of rubber farmers in Bukit Baling Village, sell the Bokar using marketing channels involving large traders in marketing bokar to rubber processing factory. The rest of the 19 farmers, or 31.6 percent, chose marketing channels II, and nine farmers, or 15.1 percent, chose marketing channels III.
Previously farmers sold their bokar at the rubber auction market. Because traders in this case, which is a small extension of the factory's hand and a small volume of bokar, farmers no longer sold their bokar products at the rubber auction market. Also, the gestation period to sell to the rubber auction market makes it difficult for farmers to get cash quickly.

In the distribution process at the marketing channel I, rubber farmers sell bokar to large traders in the capital city of the Sakernan Subdistrict. The wholesalers are traders who make purchases in a large capacity from 
rubber farmers and collecting traders located in Bukit Baling Village. Rubber farmers sell bokar to wholesalers since the selling price of bokar is relatively high compared to traders' selling price.

The marketing channel I involved 53.3 percent of rubber farmers who sold bokar to large traders, then large traders sold it to rubber processing plants. Large traders buy bokar from farmers and buy from other rubber farmers so that the volume of buying and selling of large traders becomes larger. Bokar weight shrinks from 4-10 percent of the weight when purchasing from rubber farmers since bokar is not directly sold on the day of purchase from rubber farmers. Usually, bokar are stored on average for up to three days until all the bokar is collected.

This marketing channel II is the same as the first channel, namely rubber farmers distributing their bokar to the large traders (wholesaler). This marketing channel II is longer if compared to marketing channel I as it involves middlemen. Rubber farmers sell bokar to middlemen/traders who are in Bukit Baling Village. Furthermore, the collecting traders marketed the bokar to large traders in the capital city of Sakernan subdistrict. Rubber farmers sell bokar to the collectors because they have borrowed money/goods from the collectors, kinship/family, customers, and neighbours.

Almost the same as why farmers sold the bokar to traders, collectors also sold the bokar to certain large traders because they still have kinship/family. The other reason, collectors have borrowed money from wholesalers, and the selling prices to wholesalers are not too far away with rubber processing materials marketed to factories, which are only in IDR's range. 500 - 800 / $\mathrm{kg}$.

Marketing channel II involved 31.6 percent of the farmers who sold rubber-based materials to the collectors, and then the collecting traders sold them to wholesalers. Wholesalers then sell the bokar purchased from collector traders to rubber processing plants. Sales weight experienced shrinkage ranged from 5 percent of the initial weight of purchases from rubber farmers. In comparison, the weight will experience depreciation ranged from 5-10 percent of the volume of purchases from the Middleman. This condition is caused by the bokar being not directly sold on the day of purchase from rubber farmers but stored an average of two days in the soaking pool. The collectors' distance to large traders is quite far, around $13 \mathrm{~km}$ so that depreciation reaches 5 percent.

Activities on the marketing channel III are farmers selling bokar to collecting traders in Bukit Baling Village. Furthermore, the collecting traders' market of the bokar purchased from rubber farmers to rubber processing plants. Rubber farmers sell the bokar to collectors at the marketing channel III because they have kinship/family relationships with collectors. Other reasons include customers, neighbours, borrowing money/goods with collectors.

Marketing channel III involved 15.1 percent of all farmers, who sold the bokar to the collectors, then the Middleman sold the bokar to the rubber processing plants. Collectors buy bokar from farmers and buy bokar material from other rubber farmers so that the volume of buying and selling of traders is a lot. There is a depreciation in sales volume around 5 percent of the volume of purchases from rubber farmers. This is due to the fact that rubber processing materials are not directly sold on the day of purchase from rubber farmers but are stored for an average of 2 days in the storage pond and the distance of the collectors to the rubber processing plant is approximately $12 \mathrm{~km}$.

The area with high rubber prices is Mandiangin subdistrict that have the most rubber farmers in Sarolangun district. Besides, the rubber planting area in Mandiangin sub-district is the largest in Sarolangun District. The selected village is Jati Baru village. The rubber sold in this village is not as rectangular as usual, but a pile of rubber after the mold, then put in a sack. This immersion activity is carried out with the aim of obtaining heavier rubber weights. Here, farmers do not measure quality standards, both stale (basi) and dry rubber content. Resultant from this process, affecting in lower prices received. This is done assuming that there is no difference in prices for clean and dry rubber than rubber with heavier weight. The Bokar distribution in this area can be seen as follow.

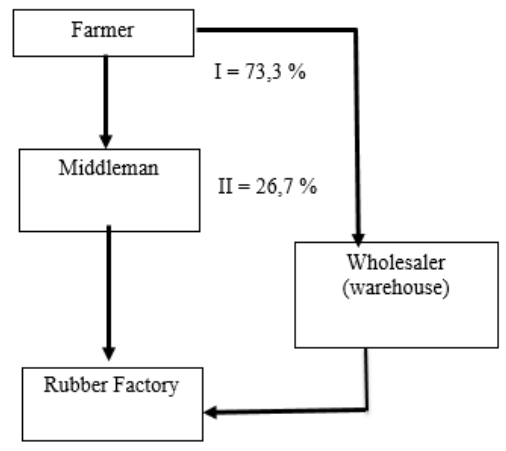

Figure 2. The Marketing Channel in the Region with High Price

Farmers who use this marketing channel are quite a lot. This channel is divided into two tracks. In the first channel, as many as 73.3 percent of farmers channeled rubber through village traders. As for the second channel, Farmers immediately sold their bokar to a large warehouse in the city. with transportation costs of around IDR. $800 / \mathrm{kg}$, transporting bokar from Jati Asih village to Joni's warehouse in Jambi, even though farmers still sell it to collecting traders. About 26.7 percent use channel two. Although the distance to Joni's warehouse 
is very far, more than $100 \mathrm{~km}$ with about 3 hours by truck, the farmers have calculated directly to distribute bokar directly to the storage warehouse. One of the advantages of this marketing channel is that farmers quickly obtain capital loans. Traders can provide loans without providing conditions for farmers who want to borrow money, so they feel helped. Farmers usually sell to traders every 3-5 days if it doesn't rain. When it rains, it is usually seven days to sell to traders.

\subsection{Margin and Marketing Efficiency in Rubber Marketing to Crumb Rubber Factories}

Marketing margin is the price difference from the two levels of the marketing channel, which is the difference between the selling price and the purchase price. The marketing margin in this study looked at the price differences obtained from the selling price of rubber ingredients from farmers and the selling price of rubber processing materials between traders and rubber processing plants.

The lowest marketing margin is indicated by marketing channel I, which is equal to IDR. 1,375 per kilogram. This is because farmers directly sell bokar to wholesalers, thereby reducing middlemen's involvement in the marketing chain of rubber processing in the village of Bukit Baling. Marketing channel II margin is IDR. 1,750 per kilogram, channel III marketing margin of IDR. 1,575 per kilogram. Marketing channel II is the marketing channel with the highest marketing margin because in marketing channel II farmers sell bokar to middlemen, they sell to wholesalers, and the wholesalers sell to the rubber processing factory. The length of the marketing chain causes a high marketing margin on marketing channel II.

The data shows that the longer the marketing chain of bokar from farmers to processing plants, the greater the marketing margins. Conversely, the shorter the marketing channels for farmers to processing plants (consumers), the smaller the rubber's marketing margins. In marketing channel, I, farmers directly sell to wholesalers, so the price received by farmers is greater than the marketing channel II with prices received by farmers of IDR. 5,200 per $\mathrm{kg}$, and on the marketing channel III IDR. 5,250 per $\mathrm{kg}$ and marketing channel I is IDR. 5,600 per kg.

Marketing efficiency in this study is seen from two angles, namely the institution's Efficiency and the Efficiency of the marketing channel. According to[7], an efficient marketing institution, if marketing costs are lower than the value of the marketed product, the lower the marketing costs of the marketed product, the more efficiently it conducts marketing [10][11].
Components that are taken into account in assessing a marketing agency's Efficiency are the total marketing costs and the product's total value. Total marketing costs are all costs incurred by marketing agencies in marketing rubber ingredients. The product's total value is the product of the selling price with the volume of products made by each marketing agency [12]. The Efficiency of marketing institutions Channel I in Bukit Baling Village is 9.85 .

The marketing institutions involved in marketing channels II are Middleman and wholesalers, both of which are already efficient. Middleman with a marketing efficiency value of 4.43 percent, while the wholesaler amounted to 11.10 percent. The second value of marketing efficiency is below 33 percent, which means the second marketing agency in marketing channel II is classified as efficient. Furthermore, the Efficiency of marketing institutions in marketing channel III is 11.47 percent.

All institutions involved in the bokar marketing channel are classified as efficient because the efficiency value is below 33 percent. However, the most efficient marketing institutions are collector traders with a percentage of efficiency value of 4.43 percent on marketing channel II, followed by wholesalers in marketing channel I by 9.96 percent, and wholesalers on marketing channel II 11.10 and by 11.42 percent of Middleman on the marketing channel III.

Marketing costs incurred on marketing channels II are marketing costs that are the largest compared to marketing costs incurred by other marketing agencies. This is because this marketing channel involves many marketing agencies in marketing rubber ingredients. The marketing costs incurred in marketing channels I are the lowest marketing costs with an average sales volume of $85,075 \mathrm{~kg} /$ month with marketing costs of IDR. 687 per $\mathrm{kg}$. Marketing costs at marketing channel III are IDR. 783 per $\mathrm{kg}$ with an average sales volume of $5,950 \mathrm{~kg} / \mathrm{month}$. Marketing channels are considered efficient when delivering rubber processing results from farmers to rubber processing plants at the lowest possible cost. The most efficient marketing channel based on the lowest marketing costs is marketing channel I because the sales volume is more than the marketing channel III.

The lowest marketing profit is indicated by the marketing channel I of IDR. 851 per $\mathrm{kg}$, this is because wholesalers who buy the bokar from farmers directly sell to a rubber processing factory for IDR.5,300 per $\mathrm{kg}$ with a marketing cost of IDR. 624 per kg. The advantages of marketing channels II and III are IDR 856 per $\mathrm{kg}$ and IDR. 1,332 per kg, respectively. The high purchase price of bokar from farmers causes the lowest profits obtained 
by wholesalers on the marketing channel with other marketing channels' benefits. That the lower the profit gained from the marketing channel for bokar, the more efficient the marketing channel will be. The low profit obtained from the marketing channel I compared to other marketing channels makes this marketing channel I more efficient than other marketing channels.

Looking at the marketing channel efficiency indicators carried out in marketing rubber slab ingredients, including marketing costs, and marketing agency profits. It can be concluded that the most efficient marketing channel for rubber materials in the village of Bukit baling, Sakernan Subdistrict, is marketing channel I followed by marketing channel III and marketing channel II . So that it can be concluded that the shorter the marketing channel, the more efficient the marketing channel.

Marketing margins show price differences from two levels of the marketing chain. Marketing margins are influenced by the selling price and purchase price of rubber [13][14]. The marketing margin shows the difference in prices paid by consumers and the prices received by farmers. The marketing margin in Jati Asih Village in Mandiangin sub-district shows that there are differences in marketing margins at the level of the Middleman and wholesalers. The marketing margin at the level of the Middleman is IDR. 1,725 for every one kilogram of rubber processed material, and for the wholesaler, the marketing margin is IDR. $1400 / \mathrm{Kg}$. Furthermore, the marketing costs at the level of the Middleman are IDR. 570 per $\mathrm{kg}$ with a profit margin of IDR. 1,155 each $\mathrm{kg}$, followed by marketing costs for a wholesaler of IDR. Four hundred each $\mathrm{kg}$ and profit margins of IDR. 1,000 each $\mathrm{kg}$.

Marketing efficiency can also be seen from each rubber marketing channel found in Jati Asih Village. The marketing channel is a path through which the flow of goods from producers to intermediaries and finally to consumers. There are two marketing channels in Jati Asih Village, from farmers to rubber processing factories. The two channels are:1. Farmer - Village Middleman Rubber Factory and 2. Farmer - Wholesaler (Warehouse)- Rubber Factory.

The farmer's selling price usually does not refer to the KKK 100 percent, and the water content in farmers can be very high, up to 40 percent. So, village middleman takes that into account. In smooth transportation conditions, it is only natural for farmers to be sold to collectors, and collectors directly sell to crumb rubber mills. The trader will then calculate the cost, the cost of transportation, loading and unloading, all official and unofficial levies, and depreciation since in the accumulation and transportation of water content decreases, plus profit margins.

The price of rubber in Jambi Province varies greatly between districts at the same time. According to 2017 price data at the farmer level [5], the highest prices occur in Sarolangun District, IDR. 11,110 per kilogram and the lowest in Muaro Jambi District IDR. 8,670 per kilogram. It means a huge price difference between the two regions, which is IDR 2,440 per kilogram. The price difference condition that is too high must be minimized, especially Muaro Jambi Regency is adjacent to the crumb rubber processing plant, which is the 6th most extensive area of land and rubber producer in Jambi Province. Therefore, it is necessary to identify the factors that cause it. Compared to the distance from Mandiangin District, which reached a 3 hours trip to the rubber processing plant, PT Remco in Pemayung Jambi.

The quality of bokar is essential in determining the price by traders and manufacturers. The indicators included in the quality of bokar are Dry Rubber Content (KKK), the treatment before being sold to the factory, used freezing materials and its size. The dry rubber content of bokar produced in high-priced areas is higher at 50-60 percent compared to dry rubber content (DRC) in production areas with low prices of only 40-45 percent. This difference is due to the high sales price in the regions two weeks once and once a month.

Based on conditions in high rubber prices, the price of rubber in the low-price area can be increased if the quality of rubber is improved, especially the frequency of bokar sales is not done every day but two weeks one time or even once a month. This is due to current smoother transportation and the distance from the village to the sub-district and to the rubber factory is very far. Besides that, even though bokar storage is carried out in the Pond, using ant acid freezing material and not mixing bokar with other ingredients. The low price of rubber can actually be increased. This condition will be achieved if farmers are incorporated in farmer groups or cooperatives. Before the price of rubber felt in the last 5 years, actually in the village of Bukit Baling, there was an auction, but because very few traders came and farmers who sold it would be difficult for farmers to sell rubber two weeks one time or one month once due to family needs which must be fulfilled at all times. This condition was since the farmers do not have or lack household finances, even though in terms of rubber productivity in low price areas, this is relatively high.

Understanding the frequency of sales is the frequency of self-sale, frequency of tapping, and shrinkage. The frequency of bokar sales between high and low-price areas is different, i.e., if the price area is high in the 
frequency of sales two weeks once and once a month, while in the low-price area 3 days and once a week. This condition causes the rubber dry content in the high price area to be higher than the low-price area. The distance between the more extended frequency of sales in the high price area is also due to the distance processing.

Another difference between high and low-price areas is the frequency of tapping. High prices generally apply the S2 / D2 tapping system or tapping a half circle with a tapping day two days one-time tapping. In areas with low prices, the tapping system is generally S2 / D1 and S1 / D1, tapping every day with tapping fields that are halfcircle, but there is also a circle. This condition makes it seem as if rubber productivity in the low-price area is

\section{CONCLUSION}

1. The pattern of marketing rubber in the regions with low prices of bokar has three marketing channels, while in areas with high prices, there are only 2 .

2. Marketing institutions involved in marketing bokar produced by farmers are Middleman, wholesalers, and crumb rubber factories, where efficient marketing channels are the shortest channel, both in areas with high and low prices. The reason for the high difference in rubber prices between the two districts is the difference in the quality of rubber materials, the marketing mechanism, and the frequency of bokar sales.

\section{Acknowledgment}

Thanks to DFG has funded this research under ABS Funding.

\section{REFERENCES}

[1] W. Cahyadi, Analisis dan Aspek Kesehatan Bahan Tambahan Pangan. Bumi Aksara: Jakarta, 2011.

[2] International Rubber Study Group, "Rubber Statistical Bulletin. Singapore," 2017.

[3] H. Zahri, "Character Education Management," Tarbawi J. Keilmuan Manaj. Pendidik., vol. 4, no. 02, p. 191, 2013, doi: 10.32678/tarbawi.v4i02.1230.

[4] Dinas Perkebunan Provinsi Jambi, Statistik Perkebunan. Dinas Perkebunan Provinsi Jambi, 2019.

[5] Dinas Perkebunan Provinsi Jambi, Harga Komoditas Perkebunan Jambi dalam Bulanan. Dinas Perkebunan Provinsi Jambi, 2018.

[6] T. Kopp, Z. Alamsyah, R. S. Fatricia, and B. Brümmer, "Have Indonesian Rubber Processors Formed a Cartel? Analysis of Intertemporal higher. Productivity in low-price areas is 203 $\mathrm{kg} / \mathrm{ha} / \mathrm{month}$, while in regions with high $150 \mathrm{~kg} / \mathrm{ha} / \mathrm{month}$ prices. Whereas rubber plants in high-productivity areas are better maintained, and the seeds used are also better. Sales frequency conditions relatively more often affect the depreciation of bokar as long as they are marketed to the rubber factory. Bokar, whose sales are three days one time and one week once in a region with a low price, has a larger depreciation percentage of 10 percent than an area that sells two weeks and one month once, which is only five percent. This high bokar depreciation is a loss for marketing agencies because it increases transportation costs due to increasing volume. Though the volume increases because of the large amount of water content.

Marketing Margin Manipulation," CRC990 Discussion Pap. Ser., vol. 3, pp. 1-35, 2014, [Online]. Available: resolver.sub.unigoettingen.de/purl/?webdoc-3908.

[7] Soekartawi, Analisis Usahatani. UI - Press : Jakarta, 1995.

[8] Gabungan Perusahaan Karet Indoneisa, "Indonesian Rubber Industry,” GAPKINDO, 2018. https://gapkindo.org/.

[9] A. R. Anuja, A. Kar, V. C. Mathur, and G. K. Jha, "Input Delivery, Processing, and Marketing of Natural Rubber: The Role of Producers' Cooperatives in Kerala," Agric. Econ. Res. Rev., vol. 25, no. 2012, pp. 379-386, 2012, [Online]. Available: http://ageconsearch.umn.edu/bitstream/136757/2/3AR-Anuja.pdf.

[10] D. Y. Giroh, H. Y. Umar, and W. Yakub, "Structure, conduct and performance of farm gate marketing of natural rubber in Edo and Delta States, Nigeria," African J. Agric. Res., vol. 5, no. 14, pp. 1780-1783, 2010, doi: 10.5897/AJAR09.356.

[11] A. M. Kizito, "The structure, conduct, and performance of agricultural market information systems in Sub-Saharan Africa.," Diss. Michigan State Univ. USA., vol. 53, no. 9, pp. 1689-1699, 2011.

[12] D. Napitupulu, "Kajian Tataniaga Karet Alam: Upaya Peningkatan Kesejahteraan PetanI Natural Rubber Marketing Study: An Effort to Improve Farmers Welfare," vol. 29, no. 1, pp. 76-92, 2011.

[13] T. Kopp, B. Brumer, Z. Alamsyah, and R. S. Fatricia, "Welfare implications of intertemporal marketing margin manipulation," Br. Food J., vol. 119 Editio, pp. 1656-1671, 2017.

[14] Hasyim AI, “Agricultural Marketing .," Fac. Agric. Lampung Univ. Bandar Lampung., 2012. 